\title{
Główny Urząd Statystyczny jako źródło informacji istotnych w określeniu stanu finansów publicznych Rzeczypospolitej Polskiej. Gospodarka finansowa Głównego Urzędu Statystycznego
}

Central Statistical Office as a source of information that is relevant in determining the state of the public finances of the Republic of Poland. The financial management of the Central Statistical Office

Streszczenie. W opracowaniu omówiono znaczenie statystyki publicznej w finansach publicznych, strukturę i gospodarkę finansową Głównego Urzędu Statystycznego i innych jednostek sektora finansów publicznych z nim powiązanych oraz wskazano przykładowe rozwiązania prawne w polskim porządku finansowoprawnym, które podkreślają istotę i aktualność podejmowanej tematyki. 
Autor omawia znaczenie statystyki publicznej w procesie sprawnego zarządzania finansami publicznymi oraz prowadzenia jawnej i transparentnej gospodarki środkami publicznymi. Analizując rolę GUS w sektorze finansów publicznych, autor stwierdza, że katalog zadań nakładanych na GUS z perspektywy finansów publicznych jest obszerny i dynamiczny. Powinno to skutkować zwiększeniem nakładów na finansowanie zadań wykonywanych przez GUS w celu podnoszenia jakości uzyskiwanych wyników prowadzonych badań statystycznych.

Słowa kluczowe: gospodarka finansowa Głównego Urzędu Statystycznego; finanse publiczne.

Abstract. In the elaboration the author discussed the meaning of the public statistics in public finances, the structure and the financial activity of the Central Statistical Office (CSO) and other units of public sector, which is related with it.

Besides, the author indicates example of legal solutions in the Polish order financial which underlines the importance and actualness of undertaken subject matter. Also, the author underlines the meaning of the public statistics in the process of the efficient financial management public and conducts of the transparent economy with public measures. The author constates that the catalogue of tasks of $\mathrm{CSO}$, from the perspective of public finance, is extensive and dynamic.

Keywords: financial management of the Central Statistical Office; public finance.

\section{Wstęp}

Główny Urząd Statystyczny jest centralnym organem administracji rządowej, a zatem również jednostką sektora finansów publicznych ${ }^{1}$, która wykorzystuje środki publiczne na realizację zadań o charakterze publicznym.

W opracowaniu podjęto próbę oceny znaczenia statystyki publicznej w procesie sprawnego zarządzania finansami publicznymi oraz prowadzenia jawnej i przejrzystej gospodarki środkami publicznymi. Liczne rozwiązania prawne nawiązujące do badań statystycznych Głównego Urzędu Statystycznego ${ }^{2}$, wynikające zarówno z ustawy z dnia 29 czerwca

Dalej: j.s.f.p.

Dalej: GUS. 
1995 r. o statystyce publicznej ${ }^{3}$, jak i z ustawy z dnia 29 sierpnia 2009 r. o finansach publicznych ${ }^{4}$ oraz wielu innych ustaw zaliczanych do aktów prawa finansowego, wskazują na istotną rolę GUS w systemie transparentnego gromadzenia środków publicznych i ich właściwego rozdysponowania.

Katalog zadań nakładanych na GUS z perspektywy finansów publicznych jest obszerny i podlegający dynamicznemu rozwojowi. Z kolei zwiększanie zadań GUS w pozyskiwaniu informacji niezbędnych w określania stanu finansów publicznych w RP czyni poruszaną tematykę bardzo aktualną.

W opracowaniu omówiono również strukturę i gospodarkę finansową GUS i innych j.s.f.p. z nim powiązanych. W ostatniej części wskazano na przykładowe rozwiązania prawne w polskim porządku finansowoprawnym, które podkreślają wagę i aktualność podejmowanej tematyki.

\section{Znaczenie statystyki w finansach publicznych. Zagadnienia ogólne}

Ustawa z dnia 29 czerwca 1995 r. o statystyce publicznej określa zasady i tworzy podstawy rzetelnego, obiektywnego, profesjonalnego i niezależnego prowadzenia badań statystycznych statystyki publicznej ${ }^{5}$, których wyniki mają charakter oficjalnych danych statystycznych, a ponadto ustala organizację i tryb prowadzenia tych badań i zakres związanych z nimi obowiązków. Zgodnie z postanowieniami ww. ustawy, statystyka publiczna jest rozumiana jako system zbierania danych statystycznych, gromadzenia, przechowywania i opracowywania zebranych danych oraz ogłaszania, udostępniania i rozpowszechniania wyników badań statystycznych jako oficjalnych danych statystycznych.

Dzięki statystyce publicznej społeczeństwo, organy państwa i administracji publicznej oraz podmioty gospodarki narodowej uzyskują rzetel-

3 Ustawa z dnia 29 czerwca 1995 r. o statystyce publicznej (tekst jedn. z 2016 r., poz. 800, dalej: ustawa o statystyce publicznej).

Tekst jedn. Dz.U. 2013 r., poz. 885, ze zm., dalej: u.f.p.

Dalej: badania statystyczne. 
ne, obiektywne i systematyczne informacje o sytuacji ekonomicznej, demograficznej, społecznej oraz dotyczące środowiska naturalnego. Informacje powyższe stanowią substrat podejmowanych badań statystycznych $^{6}$. Uznać zatem należy, że statystyka publiczna, zarówno w sektorze publicznym, jak i w sektorze prywatnym, pełni bardzo istotną rolę, gdyż funkcjonowanie szeroko pojętych finansów bez danych statystycznych jest obecnie niemożliwe. Podkreślić należy, że obszar badań statystycznych jest bardzo szeroki, gdyż jego przedmiotem może być każda dziedzina życia społecznego i gospodarczego oraz występujące w nich zjawiska. Wyznacznikiem tego, czy dane zjawisko może być przedmiotem tych badań, jest możliwość jego obserwowania i analizowania z wykorzystaniem metod statystycznych. Uzyskane w wyniku przeprowadzonych badań wyniki powinny być społecznie użyteczne, uzasadnione względami celowościowymi, czy też niezbędne w konkretnej dziedzinie np. dziedzinie prawa.

Zadania nałożone na GUS w ustawie o statystyce publicznej wykonywane są m.in. przez służby statystyki publicznej, tj. Prezesa Głównego Urzędu Statystycznego ${ }^{7}$ oraz podległych mu dyrektorów urzędów statystycznych i innych jednostek statystyki tworzonych w trybie określonym w ustawie o statystyce publicznej, np. jednostek obsługi statystyki publicznej, agencji statystycznych. Wszystkie podmioty i jednostki, o których mowa wyżej, powinny wykonywać swoje zadania rzetelnie, zgodnie z etyką zawodową statystyka oraz z pełnym poszanowaniem tajemnicy służbowej, która obliguje do tego, aby poznane w czasie wykonywania zadań dane jednostkowe zachowane były w tajemnicy wobec osób trzecich. Przestrzeganie ww. zasad gwarantuje obiektywną ocenę obserwowanych zjawisk, jak również bezpieczne ich wykorzystanie bez narusze-

$6 \quad$ Por.: Program badań statystycznych statystyki publicznej na rok 2015, sierpień 2014 r. Załącznik do rozporządzenia Rady Ministrów z dnia 27 sierpnia 2014 r. w sprawie programu badań statystycznych statystyki publicznej na rok 2015 (Dz.U. 2014 r., poz. 1330) oraz rozporządzenie Rady Ministrów z dnia 19 stycznia 2015 r. zmieniające rozporządzenie w sprawie programu badań statystycznych statystyki publicznej na rok 2015 (Dz.U. 2015 r., poz. 156).

Dalej: Prezes GUS. 
nia praw i wolności podmiotów oraz jednostek udzielających właściwych informacji.

Katalog uprawnień jednostek realizujących zadania stawiane statystyce publicznej jest obszerny. W art. 5 ustawy o statystyce publicznej wskazano, że statystyka publiczna jest uprawniona do zbierania danych ze wszystkich dostępnych źródeł określonych szczegółowo w programie badań statystycznych albo w odrębnych ustawach, jak również do gromadzenia danych statystycznych od podmiotów gospodarki narodowej oraz o nich i ich działalności (dane indywidualne), a także danych statystycznych od osób fizycznych oraz o nich, dotyczących ich życia i sytuacji (dane osobowe), z wyłączeniem danych chronionych tajemnicą dowodową - na podstawie odrębnych ustaw. Warto podkreślić, że dane indywidualne i dane osobowe, które są zbierane i gromadzone w badaniach statystycznych, są poufne i podlegają szczególnej ochronie, bowiem są objęte tajemnicą statystyczną. Dane te mogą być wykorzystywane wyłącznie do opracowań, zestawień i analiz statystycznych oraz do tworzenia przez służby statystyki publicznej operatu do badań statystycznych prowadzonych przez służby statystyczne. Dlatego też pracownicy służb statystyki publicznej, rachmistrze spisowi, ankieterzy statystyczni oraz inne osoby wykonujące czynności w imieniu i na rzecz statystyki publicznej, którzy mają bezpośredni dostęp do danych indywidualnych i danych osobowych, są obowiązani do bezwzględnego przestrzegania tajemnicy statystycznej, zaś przed dopuszczeniem do wykonywania tych czynności muszą złożyć w urzędzie statystycznym albo innej jednostce organizacyjnej służb statystyki publicznej pisemne przyrzeczenie w tej sprawie.

Jedną z fundamentalnych zasad wyrażonych w ustawie o statystyce publicznej jest zasada równości i jawności (powszechności) wyników obliczeń, opracowań i analiz dokonanych na podstawie zebranych w badaniach danych (wynikowych informacji statystycznych). Statystyka publiczna zapewnia bowiem równoprawny, równorzędny i równoczesny dostęp do wynikowych informacji statystycznych, a w szczególności do podstawowych wielkości i wskaźników.

Badając znaczenie statystyki w finansach publicznych, należy również dokonać syntetycznej analizy statusu organów powiązanych z GUS. 
Organem opiniodawczo-doradczym w sprawach statystyki jest Rada Statystyki, która działa przy Prezesie Rady Ministrów, a jej skład jest powoływany na pięcioletnią kadencję. Do jej zadań należy m.in. ${ }^{8}$ ustalanie na każdy następny rok projektu programu badań statystycznych i ocena realizacji tego programu, jak również formułowanie opinii w sprawach mających istotne znaczenie dla rozwoju statystyki publicznej oraz opiniowanie projektu wydatków budżetowych na badania statystyczne.

Badania statystyczne prowadzi, co do zasady, Prezes GUS ${ }^{9}$. Katalog zadań nałożonych na Prezesa GUS jest rozbudowany i został określony w art. 25 ustawy o statystyce publicznej. Mając na względzie zakres przedmiotowy niniejszego opracowania, należy wymienić zwłaszcza następujące zadania: rozpoznawanie zapotrzebowania na informacje i analizy statystyczne i przygotowywanie na tej podstawie projektów programów badań statystycznych oraz ich przedstawianie Radzie Statystyki, organizowanie i prowadzenie badań statystycznych oraz ustalanie ich metodologii; zbieranie, gromadzenie i opracowywanie danych statystycznych oraz ich analizowanie; przeprowadzanie spisów powszechnych; przechowywanie danych statystycznych; udostępnianie i rozpowszechnianie wynikowych informacji statystycznych, w tym podstawowych wielkości i wskaźników; opracowywanie i ogłaszanie prognoz demograficznych $^{10}$ oraz statystycznych prognoz gospodarczych i społecznych; przedstawianie Prezydentowi, Sejmowi i Senatowi, organom administracji rządowej, Najwyższej Izbie Kontroli ${ }^{11}$, Narodowemu Bankowi Polskiemu $^{12}$, organom jednostek samorządu terytorialnego ${ }^{13}$ oraz innym instytucjom rządowym wynikowych informacji statystycznych w zakresie, w terminach i w formach określonych w programie badań statystycznych; prowadzenie krajowych rejestrów urzędowych: podmiotów gospodarki narodowej i podziału terytorialnego kraju; prowadzenie szkolenia,

\footnotetext{
Szerzej: art. 15 ustawy o statystyce publicznej.

Rada Ministrów na wniosek Rady Statystyki może w programie badań statystycznych ustalić, że badanie statystyczne będzie prowadzone przez inny organ.

Por. art. 35 ustawy o statystyce publicznej.

Dalej: NIK.

Dalej: NBP.

Dalej: j.s.t.
} 
dokształcania i doskonalenia w dziedzinie statystyki oraz popularyzacja wiedzy o statystyce ${ }^{14}$. Z organizacyjnego punktu widzenia istotne jest również to, że Prezes GUS:

a) tworzy i znosi w drodze zarządzenia urzędy statystyczne, którymi kierują dyrektorzy powoływani i odwoływani przez Prezesa GUS ${ }^{15}$;

b) tworzy jednostki obsługi statystyki publicznej i określa w drodze zarządzenia zakres ich zadań i organizację;

c) powołuje rachmistrzów spisowych, ankieterów statystycznych, rzeczoznawców i społecznych korespondentów statystycznych;

d) może tworzyć, w drodze zarządzenia, agencje statystyczne do zorganizowania pracy rachmistrzów spisowych i ankieterów statystycznych oraz do wykonywania na zamówienie opracowań wspomagających inne systemy informacyjne administracji publicznej; oddelegowywania pracowników do wykonywania prac statystycznych w organach administracji rządowej i samorządowej, a także do prowadzenia na indywidualne zamówienia badań statystycznych nieobjętych programem badań statystycznych oraz wykonywania na zlecenie dodatkowych opracowań i analiz, wykorzystując w tym celu również dane zgromadzone w badaniach objętych programem badań statystycznych.

Przy Prezesie GUS działa Naukowa Rada Statystyczna, która jest organem opiniodawczo-doradczym w sprawach metodologii badań statystycznych, zaś jej skład i tryb prac określa Prezes GUS w drodze zarządzenia $^{16}$.

14 Szerzej: art. 25 ustawy o statystyce publicznej.

5 Dyrektor urzędu statystycznego jest organem administracji niezespolonej w województwie.

16 Tj. zarządzenie nr 10 Prezesa Głównego Urzędu Statystycznego z dnia 5 maja 2005 r. w sprawie składu i trybu prac Naukowej Rady Statystycznej (Dz.Urz. GUS z dnia 23 maja 2005 r., Dz.Urz.GUS 2005, Nr 5, poz. 35 ze zm.) oraz zarządzenie nr 6 Prezesa Głównego Urzędu Statystycznego z dnia 12 września 2014 r. zmieniające zarządzenie w sprawie składu i trybu prac Naukowej Rady Statystycznej, http://bip.stat.gov.pl, (dostęp: 12.06.2016 r.). 


\section{Gospodarka finansowa GUS i źródła finansowania statystyki publicznej}

Dochody i wydatki j.s.f.p. są ujmowane w budżecie państwa uchwalanym corocznie przez Sejm w formie ustawy budżetowej na rok budżetowy (rok kalendarzowy).

Charakter zadań wykonywanych $\mathrm{w}$ ramach statystyki publicznej skutkuje koniecznością ich finansowania przede wszystkim ze środków budżetu państwa. Zadania te są finansowane do wysokości określanej corocznie w ustawie budżetowej, jednak z trzema wyjątkami. Pierwszy z nich dotyczy badań statystycznych prowadzonych przez NBP, które są finansowane ze środków NBP. Drugi dotyczy kosztów badań statystycznych, prowadzonych przez służby statystyki publicznej wspólnie z NBP lub z innymi organami i instytucjami, np. naczelnym lub centralnym organem administracji państwowej, inną instytucją rządową, wojewodą, organem j.s.t., które są finansowane ze środków budżetu państwa ujmowanych w części dotyczącej GUS oraz ze wskazanych przez prowadzącego badanie wspólne źródeł finansowania. Trzeci natomiast, dotyczy kosztów prowadzenia na indywidualne zamówienia badań statystycznych nieobjętych programem badań statystycznych, wykonywanych przez służby statystyki publicznej na zamówienie, gdyż są one pokrywane w całości ze środków zamawiającego.

Z powiązania finansów GUS z budżetem państwa wynika potrzeba uchwalenia przez Radę Ministrów programu badań statystycznych przed przyjęciem projektu ustawy budżetowej, choć ustawodawca wskazuje, że powinno to nastąpić najpóźniej równolegle z uchwaleniem projektu ustawy budżetowej. Zgodnie z przyjętą klasyfikacją budżetową, środki budżetowe państwa na finansowanie badań statystycznych są ujmowane w części dotyczącej GUS (część 58 budżetu państwa ${ }^{17}$ ), której głównym dysponentem jest Prezes GUS, będący kierownikiem tej j.s.f.p., ponoszącym

17 Zgodnie z § 1 rozporządzenia Ministra Finansów z dnia 4 grudnia 2009 r. w sprawie klasyfikacji części budżetowych oraz określenia ich dysponentów, stanowiącego załącznik do obwieszczenia Ministra Finansów z dnia 20 grudnia 2013 r. w sprawie ogłoszenia jednolitego tekstu rozporządzenia Ministra Finansów w sprawie klasyfikacji części budżetowych oraz określenia ich dysponentów (Dz.U. z 2014 r., poz. 413). 
odpowiedzialność za całość gospodarki finansowej GUS, a w związku z tym sprawujący nadzór i kontrolę nad gospodarką finansową podległych mu jednostek organizacyjnych ${ }^{18}$. Podkreślić jednak należy, że w pewnych przypadkach określone badanie statystyczne ujęte w programie badań statystycznych może być finansowane także ze źródeł pozabudżetowych, zadeklarowanych przez prowadzącego badanie.

Obecnie ze środków budżetowych w ramach części 58 budżetu państwa korzystają zarówno jednostki budżetowe GUS (dysponenci III stopnia) takie jak: GUS - Centrala, szesnaście urzędów statystycznych, Centrum Informatyki Statystycznej w Warszawie, Zakład Wydawnictw Statystycznych oraz Centralna Biblioteka Statystyczna im. Stefana Szulca, ale również Centrum Badań i Edukacji Statystycznej GUS w Jachrance będące instytucją gospodarki budżetowej.

Ustawodawca w art. 53 ustawy o statystyce publicznej nakazuje finansować działalność służb statystyki publicznej na zasadach określonych w przepisach u.f.p. W związku z powyższym do jednostek budżetowych GUS należy stosować m.in. art. 11 ust. 1 u.f.p., bowiem są one jednostkami rozliczającymi się metodą budżetową brutto (tzw. pełnymi kwotami). GUS pokrywa swoje wydatki bezpośrednio z budżetu państwa, a pobrane dochody odprowadza na rachunek dochodów tego budżetu. Dochody i wydatki budżetowe GUS są grupowane według jednolitej klasyfikacji budżetowej określonej w rozporządzeniu Ministra Finansów z dnia 2 marca 2010 r. w sprawie szczegółowej klasyfikacji dochodów, wydatków, przychodów i rozchodów oraz środków pochodzących ze źródeł zagranicznych ${ }^{19}$. Dochody GUS oraz urzędów statystycznych, jako j.s.f.p. objętych zakresem art. 9 u.f.p. związane $z$ rozpowszechnianiem i udostępnianiem wynikowych informacji statystycznych w formach określonych każdorazowo w programie badań statystycznych są dochodami budżetu państwa.

\footnotetext{
Por. art. 53 u.f.p.

Rozporządzenie Ministra Finansów z dnia 2 marca 2010 r. w sprawie szczegółowej klasyfikacji dochodów, wydatków, przychodów i rozchodów oraz środków pochodzących ze źródeł zagranicznych (tekst jedn.: Dz.U. 2014 r., poz. 1053).
} 
Zauważyć należy, że Centrum Badań i Edukacji Statystycznej GUS w Jachrance zgodnie z art. 23 ust. 1 u.f.p. odpłatnie wykonuje wyodrębnione zadania i pokrywa koszty swojej działalności oraz zobowiązania z uzyskiwanych przychodów. Taka metoda rozliczania w literaturze finansowej określana jest metodą budżetowania netto (tzw. wynikiem finansowym $)^{20}$.

Odmienne zasady finansowania dotyczą kosztów badań statystycznych wykonywanych przez służby statystyki publicznej na zamówienie. Jak już wyżej podkreślono, są one pokrywane w całości ze środków zamawiającego $^{21}$, podobnie jak koszty dodatkowych opracowań i analiz wykonywanych na zlecenie ${ }^{22}$. Jeżeli natomiast zamawiającym badania, opracowania i analizy, o których mowa wyżej, jest organ administracji państwowej, NIK i NBP, odpłatność ustala się jedynie do wysokości poniesionych kosztów, podobnie jak w przypadku, gdy zamawiającym jest uczelnia lub inna placówka naukowo-badawcza, o ile dane statystyczne będą wykorzystywane dla celów dydaktycznych, naukowych i badawczych, finansowanych ze środków państwowych.

Kończąc rozważania na temat finansowania statystyki publicznej i gospodarki finansowej jednostek z nią związanych, dodać jeszcze należy, że przekazywanie danych statystycznych w formie i trybie określonym w programie badań statystycznych, a w przypadku spisów powszechnych - w odrębnej ustawie - odbywa się odpowiednio na koszt podmiotu obserwacji statystycznej lub gestora systemu informacyjnego administracji publicznej albo prowadzącego rejestr urzędowy. W szczególnych przypadkach w programie badań statystycznych może być przewidziana odpłatność za wykonywanie stałych, dodatkowych czynności przygotowywania i przekazywania określonych danych statystycznych.

Przenosząc ww. rozwiązania finansowoprawne na grunt praktycznego ich stosowania, można pozytywnie ocenić działalność podmiotów ob-

20 Por.: Planowane dochody $i$ wydatki $w$ jednostkach służb statystyki publicznej w ustawie budżetowej na rok 2010-2013, http://old.stat.gov.pl/bip/389_6215_PLK_HTML.htm, (dostęp: 12.06.2016 r.).

21 Por.: art. 21 ust. 2 pkt 1 ustawy o statystyce publicznej.

22 Por.: art. 21 ust. 1 i ust. 2 pkt 2 ustawy o statystyce publicznej. 
jętych postanowieniami ustawy o statystyce publicznej. W informacjach o wynikach kontroli wykonania budżetu państwa w części 58 przez GUS ${ }^{23}$ dostrzec można pozytywną ocenę działalności GUS i wyniki kontroli $\mathrm{NIK}^{24}$. W ocenie NIK GUS w sposób należyty wykonuje nałożone na niego zadania, w tym rzetelnie planuje wydatki budżetu państwa oraz budżetu środków europejskich oraz realizuje zdecydowaną większość z nich z zachowaniem zasad gospodarowania środkami publicznymi, a także sumiennie prowadzi księgi rachunkowe oraz sporządza roczne sprawozdania budżetowe. Należy podkreślić, że tylko w nieznacznym zakresie występują pewne nieprawidłowości w prowadzonej gospodarce finansowej związane np. w 2013 r. z nierzetelnym dokumentowaniem zamówień publicznych, co nie rzutowało jednak na pozytywne wnioski w zakresie dokonanej kontroli.

Na poniższych wykresach zaprezentowana została wysokość dochodów i wydatków GUS w latach 2010-2015²5.

23 Najwyższa Izba Kontroli, Departament Administracji Publicznej, Informacja o wynikach kontroli wykonania budżetu państwa w 2013 r. w części 58 Główny Urzq̨d Statystyczny, KAP.410.001.09.2015, Nr ewid. 89/2015/P/15/001/KAP, Warszawa maj 2015 r., Informacja o wynikach kontroli wykonania budżetu państwa w 2013 r. w części 58 Główny Urzq̨d Statystyczny, KAP-4100-001-09/2014, Nr ewid. 78/2014/P14/001/KAP, Warszawa maj 2014 r., s. 4 oraz Informacja o wynikach kontroli wykonania budżetu państwa w 2012 r. w części 58 Główny Urzq̨d Statystyczny, KAP-4100-08-01/2013, Nr ewid. 70/2013/P13008/KAP, Warszawa maj 2013, s. 4, Informacja o wynikach kontroli wykonania budżetu państwa w 2011 r. w części 58 Główny Urzq̨d Statystyczny, KAP-4100-09-01/2012, Nr ewid. 85/2012/P/12/009/KAP, Warszawa maj 2012, s. 6, Informacja o wynikach kontroli wykonania budżetu państwa w 2010 r. w części 58 Główny Urzq̨d Statystyczny, KAP-4100-09-01/2011, Nr ewid. 64/2011/P/10/016/KAP, Warszawa maj 2011, s. 6, www.nik.gov.pl, (dostęp: 12.06.2016 r.).

24 W kontroli wykonania budżetu państwa Najwyższa Izba Kontroli stosuje trzystopniową skalę ocen: pozytywna; pozytywna, mimo stwierdzonych nieprawidłowości; negatywna. Kryteria oceny zostały zamieszczone na stronie http://www.nik.gov.pl/kontrole/standardy-kontroli-nik/.

Zgodnie z art. 182 u.f.p. sprawozdanie takie Rada Ministrów przedstawia Sejmowi i Najwyższej Izbie Kontroli, w terminie do 31 maja roku następnego. 
Wojciech Bożek

Wykres 1. Dochody budżetowe GUS w latach 2010-2015.

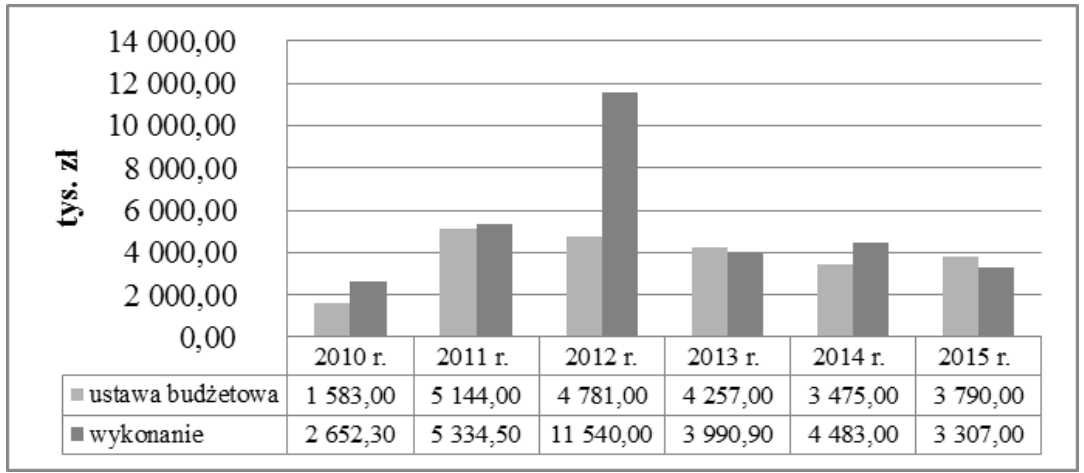

Źródło: Informacja o wynikach kontroli wykonania budżetu państwa w latach 2010-2014 r. w części 58 Główny Urzq̨d Statystyczny, www.nik.gov.pl, dostęp: 12.06.2016 r., oraz Sprawozdanie z wykonania budżetu państwa w 2015 r., www.mf.gov.pl, dostęp: 12.06.2016 r.

Z powyższego wykresu wynika, że poza rokiem 2013 i 2015 GUS osiągał określone w ustawach budżetowych dochody, a nawet je przewyższył (w 2012 r. ponad dwukrotnie).

Wykres 2. Wydatki budżetowe GUS w latach 2010-2015.

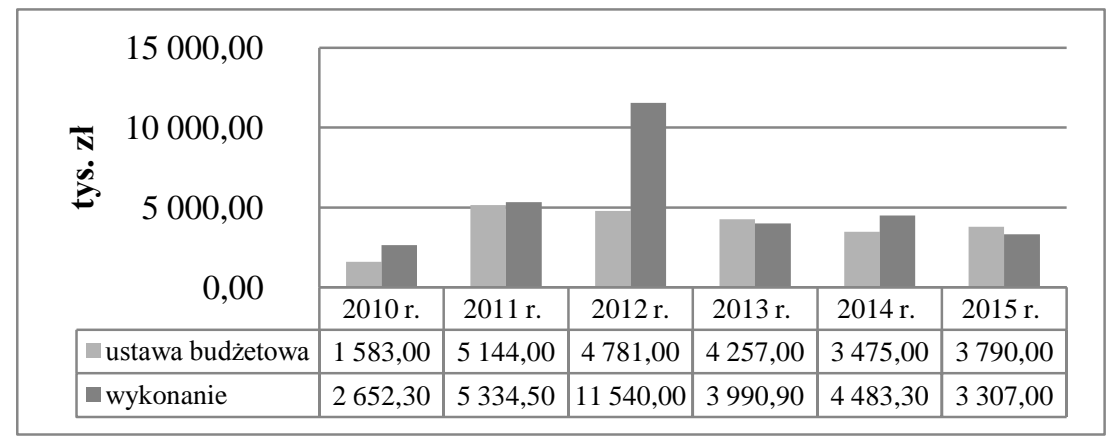

Źródło: Informacja o wynikach kontroli wykonania budżetu państwa w latach 2010-2014 r. w części 58 Główny Urzq̨d Statystyczny, www.nik.gov.pl, dostęp: 12.06 .2016 r., oraz Sprawozdanie z wykonania budżetu państwa w 2015 r., www.mf.gov.pl, dostęp: 12.06.2016 r. 
Wydatki budżetowe GUS wykonywane w kolejnych latach budżetowych wskazują, że zachowywany jest ich limit ustawowy, jednak w niektórych latach dopiero po dokonanych nowelizacjach ustaw budżetowych. W zakresie dokonywanych wydatków gospodarka finansowa GUS prowadzona jest rzetelnie i w granicach progów określonych w przepisach właściwej ustawy budżetowej.

Tabela 1. Zestawienie osiągniętych dochodów i wykonanych wydatków budżetowych GUS w latach 2010-2015.

Zestawienie wykonanych dochodów i wydatków budżetowych GUS w latach 2010-2015

\begin{tabular}{|c|c|c|c|}
\hline Rok & $\begin{array}{c}\text { Wykonane docho- } \\
\text { dy budżetowe (A) }\end{array}$ & $\begin{array}{c}\text { Wykonane wydatki bu- } \\
\text { dżetowe (B) }\end{array}$ & A/B \\
\hline 2010 r. & 2652,30 & 604150,10 & $0,44 \%$ \\
\hline 2011 r. & 5334,50 & 692960,00 & $0,77 \%$ \\
\hline 2012 r. & 11540,00 & 395062,00 & $2,92 \%$ \\
\hline 2013 r. & 3990,90 & 387276,60 & $1,03 \%$ \\
\hline 2014 r. & 4483,30 & 393743,30 & $1,14 \%$ \\
\hline 2015 r. & 3307,00 & 398102,00 & $0,83 \%$ \\
\hline
\end{tabular}

Źródło: Informacja o wynikach kontroli wykonania budżetu państwa w latach 2010-2015 r. w części 58 Główny Urząd Statystyczny, www.nik.gov.pl, dostęp: 12.06.2016 r., oraz Sprawozdanie z wykonania budżetu państwa w 2015 r., www.mf.gov.pl, dostęp: 12.06.2016 r.

Zestawienie osiągniętych dochodów i wykonanych wydatków budżetowych w analizowanym okresie wskazuje, że zasadne jest objęcie GUS gospodarką budżetową brutto, bowiem zadania wykonywane przez GUS nie są rentowne. $\mathrm{Z}$ tabeli 1 wynika, że udział dochodów w poniesionych wydatkach w danym roku budżetowym nie przekroczył 3\%. Ujawnia się w ten sposób znaczne uzależnienie działalności GUS od środków pochodzących z budżetu państwa. 


\section{Wybrane zadania nałożone na Główny Urząd Statystyczny w ustawie z 27 sierpnia 2009 r. o finansach publicznych i innych ustawach}

W ustawie o finansach publicznych nie tylko uregulowano kwestie prowadzonej gospodarki finansowej GUS oraz Centrum Badań i Edukacji Statystycznej GUS w Jachrance jako j.s.f.p., ale również zawarto w niej rozwiązania prawne, które podkreślają znaczenie danych GUS w sprawnym zarządzaniu finansami publicznymi i skutecznym realizowaniu zasady prawidłowego gospodarowania środkami publicznymi.

W pierwszej kolejności należy wskazać na to, że dane opracowywane przez GUS, a dotyczące np. produktu krajowego brutto ${ }^{26}$, są podstawą faktycznego realizowania istotnej zasady jawności i przejrzystości w finansach publicznych. Zgodnie bowiem z art. 38 u.f.p. Minister Finansów ogłasza w terminie do 31 maja roku następnego w drodze obwieszczenia w Dzienniku Urzędowym Rzeczypospolitej Polskiej „Monitor Polski” kwotę i relację do $\mathrm{PKB}^{27}$ : państwowego długu publicznego ${ }^{28}$, długu Skarbu Państwa oraz niewymagalnych zobowiązań z tytułu poręczeń i gwarancji udzielonych przez Skarb Państwa, a ponadto kwotę niewymagalnych zobowiązań z tytułu poręczeń i gwarancji udzielonych przez j.s.f.p. według stanu na koniec roku budżetowego. Nie budzi wątpliwości, że dane publikowane przez GUS odgrywają tu najważniejszą rolę, a ich brak nierozerwalnie wiązałby się z niemożliwością wypełniania przez Ministra Finansów jego ustawowych obowiązków. Informacje uzyskiwane od GUS są zatem niezbędnym źródłem wiedzy potrzebnej do ukazania rzeczywistej sytuacji finansowej Rzeczypospolitej Polskiej ${ }^{29}$ i wysokości PDP oraz jego elementów składowych.

Prezes GUS pełni również ważną funkcję koordynacyjną w sprawozdawczości dotyczącej procesów związanych z gromadzeniem środków

\footnotetext{
Dalej: PKB.

Sposób obliczania i publikacji przez Prezesa GUS wartości PKB określono w ustawie z dnia 26 października 2000 r. o sposobie obliczania wartości rocznego produktu krajowego brutto (Dz.U. 2000 r., Nr 114, poz. 1188 ze zm.).

Dalej: PDP.

Dalej: RP.
} 
publicznych i ich rozdysponowaniem ${ }^{30}$. Opinia Prezesa GUS w powyższym zakresie jest bowiem uwzględniana przez Ministra Finansów, który w drodze rozporządzenia określa rodzaje, formy, terminy i sposoby sporządzania sprawozdań, jednostki obowiązane do sporządzania poszczególnych sprawozdań oraz odbiorców tych sprawozdań, a także rodzaje i zasady sporządzania sprawozdań w zakresie zobowiązań wynikających z umów o partnerstwie publiczno-prywatnym zawieranych na podstawie odrębnych ustaw przez podmioty sektora finansów publicznych ${ }^{31}$. Minister Finansów po zasięgnięciu opinii Prezesa GUS określa również w drodze rozporządzenia rodzaje, formy, terminy i sposoby sporządzania przez j.s.f.p. sprawozdań w zakresie ogółu operacji finansowych, w szczególności w zakresie należności i zobowiązań, w tym państwowego długu publicznego oraz udzielonych poręczeń i gwarancji oraz odbiorców tych sprawozdań $^{32}$. Opinie Prezesa GUS są istotne, gdyż sprzyjają nadaniu rozporządzeniom kształtu ułatwiającego w późniejszym czasie przeprowadzanie badań statystycznych i pozyskanie niezbędnych informacji z wykonania budżetu państwa ${ }^{33}$. Prezes GUS gromadzi i przetwarza dane oraz sporządza zbiorcze sprawozdania z wykorzystaniem sprawozdań określonych w przytoczonym wyżej rozporządzeniu.

Podkreślić należy, że zadania nakładane na GUS stanowią bardzo obszerny, ale również dynamicznie rozwijający się katalog, gdyż ciągle zwiększa się ich liczba, również w zakresie dotyczącym omawianych finansów publicznych ${ }^{34}$. Co więcej, również wymagania wobec statystyki publicznej zwiększają się, zwłaszcza w zakresie jakości publikowanych

30 Szerzej: A. Ostrowska, komentarz do art. 42, [w:] E. Ruśkowski, J.M. Salachna (red.), Finanse publiczne. Komentarz praktyczny, Gdańsk 2013, s. 209.

31 Por.: Rozporządzenie Ministra Finansów z dnia 4 marca 2010 r. w sprawie sprawozdań jednostek sektora finansów publicznych w zakresie operacji finansowych (Dz.U. 2014, poz. 1773).

32 Szerzej: B. Kucia-Guściora, komentarz do art. 41, [w:] P. Smoleń (red.), Ustawa o finansach publicznych. Komentarz, Warszawa 2012, s. 357-364.

33 Por. § 8 ust. 3, 5-7 i § 9 ust. 7 rozporządzenia z przypisu nr 30.

34 Por.: W. Miemiec, komentarz do art. 41, [w:] M. Karlikowska, W. Miemiec, Z. Ofiarski, K. Sawicka, Ustawa o finansach publicznych. Komentarz, Wrocław 2010, s. 133. 
danych, szybszego ich udostępniania oraz w związku z koniecznością elastycznego reagowania na potrzeby zgłaszane przez sektor publiczny.

Zakres prowadzonych badań statystycznych obejmuje nie tylko terytorium RP, ale również sprawy o zasięgu międzynarodowym, co jest konsekwencją m.in. członkostwa RP w Unii Europejskiej. Również obowiązek dostosowania polskich uregulowań prawnych do rozwiązań unijnych wiąże się z konieczności bieżącego analizowania sytuacji społeczno-gospodarczej, tworzenia strategii i programów rozwojowych, monitorowania zmian związanych z realizacją określonych strategii i sygnalizowania zjawisk niekorzystnych. Podkreślając istotę wyników badań statystycznych, przykładowo wskazać można na to, że dane ogłaszane przez Prezesa GUS są wykorzystywane w procesie realizowania nowego w porządku finansowoprawnym instrumentu przeciwdziałania negatywnym skutkom kryzysu gospodarczego, tj. stabilizującej reguły wydatkowej. Podstawę obliczeń maksymalnych stawek tych wydatków j.s.f.p. stanowi bowiem średnioroczny wskaźnik cen towarów i usług konsumpcyjnych ogółem ogłaszany przez Prezesa GUS oraz łączna dynamika PKB ${ }^{35}$. Analizując stabilizującą regułę wydatkową, wskazać również można, że Minister Finansów oblicza sumę corocznych różnic między wartością relacji wyniku nominalnego do PKB oraz poziomem średniookresowego celu budżetowego określonego w Programie Konwergencji ${ }^{36}$, aktualizując sumę różnic z uwzględnieniem rewizji danych ogłaszanych przez Prezesa GUS. Od 1 stycznia 2014 r. obowiązuje art. 38b u.f.p., zgodnie z którym Prezes GUS ogłasza, w formie komunikatu, w Dzienniku Urzędowym RP „Monitor Polski”, w terminie do 16 kwietnia wynik nominalny sektora instytucji rządowych i samorządowych podawany do wiadomości publicznej $^{37}$ za ostatnie cztery lata oraz łączną dynamikę wartości PKB

35 Por. art.112aa u.f.p.

36 Program Konwergencji jest opracowywany zgodnie z rozporządzeniem Rady (WE) nr 1466/97/WE z dnia 7 lipca 1997 r. w sprawie wzmocnienia nadzoru pozycji budżetowych oraz nadzoru i koordynacji polityk gospodarczych (Dz.Urz. WE L 209 z 02.08.1997, s. 1, ze zm.; Dz.Urz. UE Polskie wydanie specjalne, rozdz. 10, t. 1, s. 84, ze zm.).

37 Zgodnie z art. 7 rozporządzenia Rady (WE) nr 479/2009 z dnia 25 maja 2009 r. o stosowaniu Protokołu w sprawie procedury dotyczącej nadmiernego deficytu 
w cenach stałych za ostatnie sześć lat ${ }^{38}$, które są wykorzystywane przy obliczeniu maksymalnych wydatków poszczególnych j.s.f.p.

Informacje i wyniki badań statystycznych uzyskiwane od Prezesa GUS są wykorzystywane do określania relacji PDP do PKB i ustalania, w którym z tzw. progów ostrożnościowych obecnie znajduje się $\mathrm{RP}^{39}$. W zależności od uzyskanej wielkości procentowej Rada Ministrów podejmuje działania zmierzające do obniżenia relacji PDP do PKB poniżej poziomu określonego w u.f.p. ${ }^{40}$ Przykładowo, gdy wartość relacji kwoty PDP do PKB, jest większa od 55\%, na kolejny rok Rada Ministrów uchwala projekt ustawy budżetowej, w którym waloryzacja rent i emerytur nie może przekroczyć poziomu odpowiadającego wzrostowi cen towarów i usług konsumpcyjnych, ogłoszonego przez GUS za poprzedni rok budżetowy ${ }^{41}$.

Efekty działań podejmowanych przez GUS są istotne również dla sektora samorządowego. Zgodnie bowiem z art. 268 u.f.p. roczne sprawozdanie finansowe j.s.t., w której liczba mieszkańców ustalona przez GUS na dzień 31 grudnia roku poprzedzającego rok, za który sporządzono sprawozdanie, przekracza 150 tysięcy, podlega badaniu przez biegłego rewident ${ }^{42} \mathrm{w}$ celu uzyskania dodatkowego zapewnienia w zakresie prawidłowego prowadzenia gospodarki finansowej ${ }^{43}$.

załączonego do Traktatu ustanawiającego Wspólnotę Europejską (Dz.Urz.UE L 145 z 10.06.2009, s. 1, ze zm.).

38 Szerzej: R. Bucholski, komentarz do art. 38b, [w:] H. Dzwonkowski (red.), Ustawa o finansach publicznych. Komentarz prawno-finansowy, Warszawa 2014, s. 90-92.

39 Szerzej: Z. Ofiarski, komentarz do art. 86, [w:] M. Karlikowska, W. Miemiec, Z. Ofiarski, K. Sawicka, Ustawa o finansach publicznych. Komentarz, Wrocław 2010, s. 241-243.

40 Patrz: art. 86 ust. 1 pkt 2 u.f.p. oraz L. Lipiec-Warzecha, Ustawa o finansach publicznych. Komentarz, Warszawa 2011, s. 447-457.

41 Por.: P. Pomorski, komentarz do art. 86, [w:] P. Smoleń (red.), Ustawa o finansach publicznych. Komentarz, Warszawa 2012, s. 522-524.

42 Szerzej: K. Sawicka, komentarz do art. 268, [w:] M. Karlikowska, W. Miemiec, Z. Ofiarski, K. Sawicka, Ustawa o finansach publicznych. Komentarz, s. 746-748.

43 Por.: uzasadnienie do projektu ustawy o finansach publicznych, druk sejmowy nr 1181/VI kad., s. 39 oraz J. Leńczuk, komentarz do art. 268, [w:] P. Smoleń (red.), Ustawa o finansach publicznych. Komentarz, Warszawa 2012, s. 1128 i E. Stupienko, komentarz do art. 268, [w:] H. Dzwonkowski (red.), Ustawa o finansach publicznych. Komentarz prawno-finansowy, Warszawa 2014, s. 697. 
Mając powyższe na uwadze, warto również wskazać na inne ustawy z zakresu prawa finansowego, których rozwiązania prawne odwołują się do badań statystycznych GUS. Jednym z tych aktów prawnych jest ustawa z dnia 13 listopada 2003 r. o dochodach jednostek samorządu terytorialnego ${ }^{44}$, w której przy obliczaniu wysokości subwencji ogólnej dla gmin, powiatów i województw wykorzystuje się dane dotyczące liczby mieszkańców zamieszkałych na obszarze danej j.s.t. i na terytorium państwa, PKB na jednego mieszkańca, stopy bezrobocia i liczby bezrobotnych oraz gęstości zaludnienia ${ }^{45}$. Ponadto w oparciu o podaną przez Prezesa GUS średnią cenę sprzedaży drewna oraz średnią cenę skupu żyta ustala się część wyrównawczą subwencji ogólnej i wpłat poszczególnych j.s.t. ${ }^{46}$

Również w ustawie z dnia 17 grudnia 2004 r. o odpowiedzialności za naruszenie dyscypliny finansów publicznych ${ }^{47}$ dane publikowane przez Prezesa GUS mają duże znaczenie. Zgodnie z art. 26 ww. ustawy nie stanowi naruszenia dyscypliny finansów publicznych określone w tej ustawie $^{48}$ działanie lub zaniechanie, którego przedmiotem są środki finansowe w wysokości nieprzekraczającej jednorazowo, a w przypadku więcej niż jednego działania lub zaniechania - łącznie w roku budżetowym, kwoty minimalnej tj. kwoty przeciętnego wynagrodzenia miesięcznego w gospodarce narodowej w roku poprzednim. Wysokość wynagrodzenia, o którym mowa wyżej, jest ogłaszana przez Prezesa GUS w Dzienniku Urzędowym RP „Monitor Polski” ${ }^{49}$. Jeżeli nie jest możliwe ustalenie wysokości wynagrodzenia osoby odpowiedzialnej za naruszenie dyscypliny finansów publicznych, to karę pieniężną wymierza się w wysokości od 0,25 do pięciokrotności ww. przeciętnego wynagrodzenia. Od wysokości ww. wynagrodzenia zależy również miesięczne wynagrodzenie ryczałtowe wypłacane przewodniczącym, ich zastępcom, członkom komisji orzekających

44 Ustawa z dnia 13 listopada 2003 r. o dochodach jednostek samorządu terytorialnego (tekst jedn.: Dz.U. 2016 r., poz. 198.).

45 Por.: art. 2 ustawy, o której mowa w przypisie nr 43.

46 Szerzej: art. 32 ustawy wskazanej w przypisie nr 43.

47 Ustawa z dnia 17 grudnia 2004 r. o odpowiedzialności za naruszenie dyscypliny finansów publicznych (Dz.U. 2013 r., poz. 168 ze zm.).

48 W jej art. 5-16, 18 pkt 2 oraz art. 18b i 18c ustawy, o której mowa w przypisie nr 46.

49 Tj. zgodnie z art. 5 ust. 7 ustawy z dnia 4 marca 1994 r. o zakładowym funduszu świadczeń socjalnych (Dz.U. 2016, poz. 800). 
w sprawach o naruszenie dyscypliny finansów publicznych i Głównej Komisji Orzekającej w tych sprawach, oraz rzecznikom dyscypliny finansów publicznych i Głównemu Rzecznikowi Dyscypliny Finansów Publicznych oraz ich zastępcom, a także wynagrodzenie ryczałtowe za ich udział w rozprawie lub posiedzeniu. Przeciętne wynagrodzenie rzutuje również na wysokość dochodów Skarbu Państwa z tytułu zasądzonych - od uznanego odpowiedzialnym za naruszenie dyscypliny finansów publicznych - kosztów postępowania, które wynoszą 10\% tego wynagrodzenia.

\section{Zakończenie}

Kryzys finansowy zwiększył zapotrzebowanie na rzetelne i wiarygodne informacje statystyczne, które umożliwiłyby wyszukiwanie obszarów potencjalnie zagrażających stabilności finansowej RP, w tym również szeroko pojętemu ładowi finansów publicznych. Zadania nakładane na GUS są liczne i dotyczą w zasadzie każdego obszaru funkcjonowania społeczeństwa i państwa, w którym wykorzystuje się środki publiczne do zaspokajania potrzeb publicznych. Dzięki uzyskanym przez GUS danym i wnioskom płynącym z przeprowadzonych badań statystycznych możliwe jest zatem bieżące monitorowanie różnych aspektów funkcjonowania państwa. Niezależność prowadzonych badań statystycznych (od podmiotów prawa zarówno publicznego, jak i prywatnego), daje gwarancję rzetelności i obiektywizmu w pozyskiwaniu informacji o stanie finansów publicznych RP, ale również danych międzynarodowych.

Mając natomiast na względzie stosowaną metodę prowadzonej gospodarki finansowej GUS (metoda budżetowa brutto) ${ }^{50}$, niezbędne jest zabezpieczenie w ustawie budżetowej odpowiednich środków, które umożliwią prowadzenie rzetelnych, obiektywnych i wiarygodnych badań, służących prowadzeniu transparentnej polityki finansowej państwa i ukazujących rzeczywisty stan finansów publicznych i potrzebne działania władzy publicznej.

50 Poza Centrum Badań i Edukacji Statystycznej GUS w Jachrance. 
Obecne rozwiązania prawne dotyczące statystyki publicznej, a więc również GUS, w pełni przemawiają za koniecznością stosowania metody budżetowania brutto. Zauważalna jest bowiem znaczna dysproporcja między dochodami budżetowymi GUS, a jego wydatkami (tabela 1). W latach 2010-2015 wydatki GUS przewyższały jego dochody o ponad 97\%.

Członkostwo RP w UE skutkuje zwiększeniem obszaru badawczego jednostek statystyki publicznej. Duża dynamika zjawisk badanych przez GUS uzasadnia angażowanie środków publicznych w odpowiedniej podyktowanej rzeczywistymi potrzebami GUS - wysokości. Należy podkreślić, że zapotrzebowanie GUS na większe środki finansowe w najbliższej przyszłości powinno wzrosnąć. Nowe metody komunikacji społecznej, nowe narzędzia badawcze oparte na najnowszych rozwiązaniach technicznych i technologicznych wiążą się z wysokimi nakładami finansowymi. Bez wątpienia konieczne jest także doskonalenie systemu prowadzonych badań statystycznych w GUS (systemów informatycznych) w celu szybkiego udostępniania danych podmiotom zainteresowanym, utrzymania najwyższych standardów krajowych i międzynarodowych oraz wysokiej wartości poznawczej (jakości) danych statystycznych. Dodatkowo środki z budżetu państwa powinny być przeznaczone na rozwój szerokiego i aktywnego dostępu jednostek GUS do administracyjnych źródeł informacji (np. sprawozdań j.s.f.p., o których mowa w art. 42 u.f.p.).

W ocenie autora warto byłoby również dokonać przeglądu aktualnie obowiązujących przepisów prawa, zwłaszcza ustawy o statystyce publicznej, pod kątem faktycznego dostosowania rozwiązań normatywnych do celów stawianych statystyce publicznej, edukacji statystycznej, dalej zaś w celu zapewnienia procedur i instrumentów kompleksowego i kompletnego zaspokajania potrzeb informacyjnych, skrócenia czasu opracowywania wysokiej jakości wyników badań statystycznych oraz implementowania nowych rozwiązań technologicznych.

Reasumując, GUS pełni poza funkcją informacyjną i poznawczą, również funkcję porządkową, zwłaszcza z perspektywy finansów publicznych. 


\section{Bibliografia:}

Bucholski R., komentarz do art. 38b, [w:] H. Dzwonkowski (red.), Ustawa o finansach publicznych. Komentarz prawno-finansowy, Wydawnictwo Sejmowe, Warszawa 2014.

Leńczuk J., komentarz do art. 268, [w:] P. Smoleń (red.), Ustawa o finansach publicznych. Komentarz, Wydawnictwo C.H. Beck, Warszawa 2012.

Stupienko E., komentarz do art. 268, [w:] H. Dzwonkowski (red.), Ustawa o finansach publicznych. Komentarz prawno-finansowy, Wydawnictwo Sejmowe, Warszawa 2014.

Kucia-Guściora B., komentarz do art. 41, [w:] P. Smoleń (red.), Ustawa o finansach publicznych. Komentarz, C.H. Beck, Warszawa 2012.

Ostrowska A., komentarz do art. 42, [w:] E. Ruśkowski, J.M. Salachna (red.), Finanse publiczne. Komentarz praktyczny, Wydawnictwo ODDK, Gdańsk 2013.

Miemiec W., komentarz do art. 41, [w:] M. Karlikowska, W. Miemiec, Z. Ofiarski, K. Sawicka, Ustawa o finansach publicznych. Komentarz, Wydawnictwo Presscom Sp. z o.o., Wrocław 2010.

Ofiarski Z., komentarz do art. 86, [w:] M. Karlikowska, W. Miemiec, Z. Ofiarski, K. Sawicka, Ustawa o finansach publicznych. Komentarz, Wydawnictwo Presscom Sp. z o.o., Wrocław 2010.

Lipiec-Warzecha L., Ustawa o finansach publicznych. Komentarz, Wydawnictwo ABC a Wolters Kluwer business, Warszawa 2011.

Pomorski P., komentarz do art. 86, [w:] P. Smoleń (red.), Ustawa o finansach publicznych. Komentarz, C.H. Beck, Warszawa 2012.

Sawicka K., komentarz do art. 268, [w:] M. Karlikowska, W. Miemiec, Z. Ofiarski, K. Sawicka, Ustawa o finansach publicznych. Komentarz, Wydawnictwo Presscom Sp. z o.o., Wrocław 2010. 